\title{
ANALISIS FAKTOR RISIKO DIABETES MELLITUS TIPE 2 PADA USIA PRODUKTIF DENGAN PENDEKATAN WHO STEPWISE STEP 1 (CORE/INTI) DI PUSKESMAS KENDALKEREP KOTA MALANG
}

\author{
Ayu Nindhi Kistianita \\ Moch. Yunus \\ Rara Warih Gayatri \\ Fakultas Ilmu Keolahragaan Universitas Negeri Malang \\ E-mail: nindhie19@gmail.com
}

\begin{abstract}
Based on data from IDF globally the number of DM sufferers by 2015 is 415 million people and is expectedly by 2040 to increase to 642 million people. DM Type 2 is one of the four major diseases in the category of noncommunicable disease (NCDs) that should be addressed immediately. The incidence of DM type 2 is closely related to the number of age. The purpose of this study was to determine risk factor of DM type 2 at productive age using WHO STEPwise STEP 1 (core) approach at Primary Health Care Kendalkerep Malang City. The type of this research is descriptive analytic with cross sectional study design. The sample size is 88 people at Public Health Center of Primary Health Care Kendalkerep in 1-28 February 2017 which has fulfilled the criteria inclusion, obtained by Quota Sampling. The instrument used is questionnaires WHO STEPwise STEP 1 (core). Data were analyzed by univariate and bivariate analysis using chi square test. The results showed a significant correlation between DM type 2 occurrence with history of DM $(p=0.000)$, fruit and vegetable consumption ( $p=$ $0.000)$, and physical activity $(p=0.000)$.
\end{abstract}

Keyword : risk factor, DM type 2, STEPwise STEP 1 (core)

ABSTRAK : Berdasarkan data dari IDF secara global, jumlah penderita Diabetes Mellitus (DM) pada tahun 2015 sebanyak 415 juta orang dan diperkirakan pada tahun 2040 akan meningkat menjadi 642 juta orang. DM tipe 2 merupakan satu dari empat penyakit utama dalam kategori Non-Communicable Disease (NCDs) yang harus segera ditangani. Kejadian DM tipe 2 berkaitan erat dengan pertambahan umur seseorang. Penelitian ini bertujuan untuk mengetahui faktor risiko DM tipe 2 pada usia produktif menggunakan pendekatan WHO STEPwise STEP 1 (core/inti) di Puskesmas Kendalkerep Kota Malang. Jenis penelitian adalah deskriptif analitik dengan desain studi cross sectional. Besar sampel berjumlah 88 orang di Poli Umum Puskesmas Kendalkerep pada tanggal 1-28 Februari 2017 yang telah memenuhi kriteria inklusi, diperoleh dengan cara Quota Sampling. Instrumen yang digunakan yaitu kuesioner WHO STEPwise STEP 1 (core/inti). Data dianalisis dengan analisis univariat dan bivariat menggunakan uji chi square. Hasil penelitian menunjukkan adanya hubungan yang signifikan antara kejadian DM tipe 2 dengan riwayat DM ( $\mathrm{p}$ $=0,000)$, konsumsi buah dan sayur $(\mathrm{p}=0,000)$, dan aktivitas fisik $(\mathrm{p}=0,000)$.

Kata Kunci : faktor risiko, DM tipe 2, STEPwise STEP 1 (core/inti)

Secara global, jumlah penderita Diabetes

Mellitus (DM) pada tahun 2015 sebanyak 415 juta orang dan diperkirakan pada tahun 2040 akan meningkat menjadi 642 juta orang (International Diabetes Federation (IDF), 2015). Sebanyak 43\% dari 3,7 juta kematian DM terjadi sebelum berusia 70 tahun dan persentase kematian tersebut lebih banyak terjadi di negara berkembang daripada di negara maju (WHO, 2016a). Indonesia merupakan satu dari 10 negara yang memiliki jumlah penderita DM terbanyak (Mihardja dkk, 2013). Pada tahun 2015, jumlah penderita DM di 
Indonesia sebanyak 10 juta orang (IDF, 2015). Berdasarkan data dari WHO, prevalensi DM di Indonesia pada tahun 2000 yakni 8,4 juta orang dan diperkirakan pada tahun 2030 akan mencapai 21,3 juta orang (WHO, 2016b).

DM tipe 2 adalah jenis DM yang sering terjadi di masyarakat, biasanya terjadi pada orang dewasa, akan tetapi kejadian DM tipe 2 pada anak-anak dan remaja semakin meningkat (IDF, 2015). Pada DM tipe 2, sel-sel jaringan tubuh dan otot penderita tidak peka terhadap insulin atau sudah resisten terhadap insulin (resistensi insulin) (Krisnatuti dkk, 2014).

Definisi dari usia produktif adalah rentangan usia dimana orang tersebut dapat bekerja dan membiayai kehidupannya sendiri (Mihardja dkk, 2013) serta penduduk yang telah memasuki usia 15-64 tahun (Widjajanta, 2007). Akan tetapi, hal ini tidak dapat terwujud jika kelompok usia produktif terkena DM tipe 2.

maka sangat diperlukan usaha pencegahan DM tipe 2 yang tepat. DM tipe 2 dapat dicegah dengan mengendalikan faktor risikonya (Depkes, 2008a). Untuk itu, surveilans faktor risiko DM tipe 2 sangat penting karena ketika informasi mengenai level dari faktor risiko diketahui sejak dini maka akan dapat disusun intervensi dan program yang tepat (WHO, 2011). WHO telah memprakarsai suatu surveilans yang berguna untuk mengetahui faktor risiko dari NonCommunicable Disease (NCDs) yakni dengan menggunakan WHO STEPwise (WHO, 2003). Instrumen WHO STEPwise ini dapat digunakan di seluruh dunia karena telah terstandarisasi secara internasional (WHO, 2003) dan instrumen ini di desain khusus untuk surveilans faktor risiko NCDs di negara yang berpenghasilan rendah dan sedang serta khusus pada golongan umur 25-64 tahun (WHO, 2003).

Berdasarkan laporan bulanan Puskesmas Kendalkerep Kota Malang diketahui bahwa jumlah kunjungan penderita DM yang melakukan pemerikasaan pada tahun 2013 sebanyak 3561 orang dan meningkat menjadi 3896 orang pada tahun 2014. Hal ini mengakibatkan posisi penyakit DM yang sebelumnya menempati urutan ketujuh menjadi urutan ketiga dari sepuluh besar penyakit di Puskesmas Kendalkerep (Puskesmas Kendalkerep, 2015). Selain itu berdasarkan laporan tahunan PTM tahun 2015 Puskesmas Kendalkerep menempati urutan pertama dari seluruh puskesmas di Kota Malang yang jumlah angka kejadian DM tipe 2 tertinggi yakni dengan 3311 kasus (Dinas Kesehatan Kota Malang, 2016).

Berdasarkan fakta yang telah dipaparkan mengenai kejadian DM tipe 2 di Puskesmas Kendalkerep, maka secara umum tujuan penelitian ini adalah untuk mengetahui faktor risiko DM tipe 2 pada usia produktif menggunakan pendekatan WHO STEPwise STEP 1 (core/inti) di Puskesmas Kendalkerep Kota Malang.

\section{METODE}

Penelitian ini menggunakan studi analitik deskriptif dengan rancangan studi cross sectional. Penelitian dilakukan pada 1-28 Februari 2017 di poli Umum Puskesmas Kendalkerep Kota Malang. Populasi penelitian adalah seluruh pasien rawat jalan sejak tanggal 1-28 Februari 2017 di poli umum Puskesmas Kendalkerep Kota Malang yang berusia produktif (25-64 tahun). Sampel dalam penelitian ini adalah pasien rawat jalan sejak tanggal 1-28 Februari 2017 di poli umum Puskesmas Kendalkerep Kota Malang yang berusia produktif (25-64 tahun) dengan kriteria inklusi yaitu bersedia menjadi subyek penelitian, tinggal di wilayah kerja Puskesmas Kendalkerep Kota Malang (Memiliki Kartu Tanda Penduduk/KTP), merupakan pasien rawat jalan di poli umum Puskesmas Kendalkerep Kota Malang yang menderita NCDs dan pernah melakukan tes laboratorium kadar gula darah selama 3 bulan 
terakhir. Sedangkan kriteria eksklusi penelitian ini yaitu kuesioner tidak terisi secara lengkap/kosong dan pasien rawat jalan di poli umum yang berusia $<25$ tahun dan > 64 tahun. Teknik yang digunakan dalam pengambilan sampel adalah quota sampling. Perhitungan besar sampel pada penelitian ini dengan menggunakan formula Kelsey (1996):

$$
\begin{aligned}
& \mathrm{N}_{\text {Kelsey }}=\frac{\left(\mathrm{Z}_{\frac{\alpha}{2}}+\mathrm{Z} \beta\right)^{2} \mathrm{p}(1-\mathrm{p})(\mathrm{r}+1)}{\mathrm{r}\left(\mathrm{P}_{0}-\mathrm{P}_{1}\right)^{2}} \\
& \mathrm{~N}_{\text {Kelsey }} \\
& =\frac{(1,960+0,842)^{2} \times 0,37(1-0,37)(1,6+1)}{1,6(0,27 \times 0,43)^{2}}
\end{aligned}
$$
adalah jumlah penderita DM tipe 2 jenis kelamin laki-laki di Puskesmas Kendalkerep tahun 2016 sedangkan nilai

HASIL

\section{Gambaran Kejadian DM Tipe 2}

Distribusi frekuensi kejadian DM tipe 2 di Poli Umum Puskesmas
P1 adalah jumlah penderita DM tipe 2 jenis kelamin perempuan di Puskesmas Kendalkerep tahun 2016. Pada tahun 2016 orang yang menderita DM tipe 2 di Puskesmas Kendalkerep yang berjenis kelamin laki-laki sebanyak 881 orang dan perempuan sebanyak 1388 orang (Puskesmas Kendalkerep, 2016). Pada penelitian ini, nilai $r$ didapatkan berdasarkan rasio jumlah penderita DM tipe 2 (laki-laki : perempuan) di Puskesmas Kendalkerep pada tahun 2016 dan diperoleh nilai $r=1,6$. Sesuai dengan perhitungan dengan derajat kepercayaan $95 \% \quad(Z \alpha=1,96)$ dan kekuatan uji $80 \%(Z \beta=0,84)$ maka besar sampel yang dibutuhkan untuk penelitian adalah 88 orang. Instrumen penelitian menggu-nakan kuesioner WHO STEPwise STEP 1 (core/inti). Data dikumpulkan dengan teknik wawancara. Analisis data yang dilakukan berupa analisis univariat dan analisis bivariat dengan menggunakan uji chi square.

Kendalkerep Kota Malang 1-28 Februari Tahun 2017 dapat dilihat pada gambar 1.

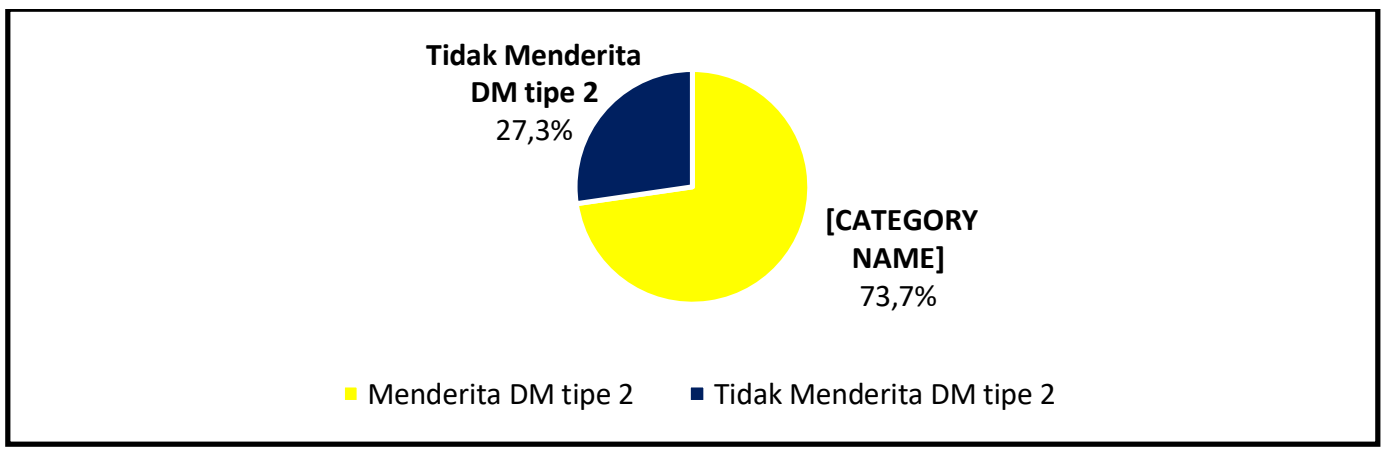

Gambar 1. Distribusi Frekuensi Kejadian DM Tipe 2 di Poli Umum Puskesmas Kendalkerep Kota Malang pada 1-28 Februari Tahun 2017

Berdasarkan pada gambar 1 diketahui bahwa pada penelitian ini dengan total responden 88 orang terdapat 64 orang $(72,7 \%)$ yang

\section{Gambaran Karakteristik Responden}

menderita DM tipe 2 sedangkan sisanya yaitu 24 orang $(27,3 \%)$ tidak menderita DM tipe 2. 
Hasil penelitian berupa

responden (merokok, konsumsi alkohol, karakteristik responden (umur, jenis kelamin, dan tingkat pendidikan), konsumsi buah dan sayur, dan akitvitas fisik) dapat dilihat pada tabel 1 .

riwayat hipertensi, riwayat DM, perilaku

Tabel 1 Distribusi Frekuensi Karakteristik Responden, Riwayat Hipertensi, Riwayat DM, Perilaku Responden Di Poli Umum Puskesmas Kendalkerep Kota Malang pada 128 Februari Tahun 2017

\begin{tabular}{|c|c|c|}
\hline Variabel & Frekuensi & Persentase (\%) \\
\hline \multicolumn{3}{|l|}{ Umur } \\
\hline 25-34 tahun & 1 & 1,1 \\
\hline 35-44 tahun & 5 & 5,7 \\
\hline 45-54 tahun & 16 & 18,2 \\
\hline 55-64 tahun & 66 & 75 \\
\hline Total & 88 & 100 \\
\hline \multicolumn{3}{|l|}{ Jenis Kelamin } \\
\hline Laki-laki & 36 & 40,9 \\
\hline Perempuan & 52 & 59,1 \\
\hline Total & 88 & 100 \\
\hline \multicolumn{3}{|l|}{ Tingkat Pendidikan } \\
\hline Tidak Sekolah (0 tahun) & 7 & 8 \\
\hline Tidak Tamat SD (1-6 tahun) & 4 & 4,5 \\
\hline Tamat SD (6 tahun) & 18 & 20,5 \\
\hline Tamat SMP (9 tahun) & 16 & 18,2 \\
\hline Tamat SMA (12 tahun) & 30 & 34,1 \\
\hline Tamat D1-D3/S1 (13-17 tahun) & 13 & 14,8 \\
\hline Pascasarjana (> 17 tahun) & 0 & 0 \\
\hline Total & 88 & 100 \\
\hline \multicolumn{3}{|l|}{ Riwayat Hipertensi } \\
\hline Ya & 45 & 51,1 \\
\hline Tidak & 43 & 48,9 \\
\hline Total & 88 & 100 \\
\hline \multicolumn{3}{|l|}{ Riwayat DM } \\
\hline Ya & 64 & 72,7 \\
\hline Tidak & 22 & 27,3 \\
\hline Total & 88 & 100 \\
\hline \multicolumn{3}{|l|}{ Merokok } \\
\hline $\mathrm{Ya}$ & 30 & 37,5 \\
\hline Tidak & 58 & 62,5 \\
\hline Total & 88 & 100 \\
\hline \multicolumn{3}{|l|}{ Konsumsi Alkohol } \\
\hline Ya & 2 & 2,3 \\
\hline Tidak & 86 & 97,7 \\
\hline Total & 88 & 100 \\
\hline \multicolumn{3}{|l|}{ Konsumsi Buah } \\
\hline Cukup & 20 & 22,7 \\
\hline Kurang & 68 & 77,3 \\
\hline Total & 88 & 100 \\
\hline \multicolumn{3}{|l|}{ Konsumsi Sayur } \\
\hline Cukup & 16 & 18,2 \\
\hline Kurang & 72 & 81,8 \\
\hline Total & 88 & 100 \\
\hline \multicolumn{3}{|l|}{ Aktivitas Fisik } \\
\hline Tinggi & 7 & 11 \\
\hline Sedang & 19 & 29,7 \\
\hline Rendah & 38 & 59,3 \\
\hline Total & 88 & 100 \\
\hline
\end{tabular}


Berdasarkan tabel 1 diketahui bahwa terdapat 88 responden, dari total responden tersebut distribusi frekuensi terbanyak pada kelompok umur 55-64 tahun yaitu sebanyak 66 orang $(75 \%)$ dan yang terendah hanya $1(1,1 \%)$ pada kelompok umur 25-34 tahun.

Mayoritas responden berjenis kelamin perempuan yaitu sebanyak 52 orang $(59,1 \%)$. sedangkan responden yang berjenis kelamin laki-laki yaitu sebanyak 36 orang $(40,9 \%)$. Untuk tingkat pendidikan yang dimiliki oleh responden terbanyak pada tingkat pendidikan Tamat SMA (12 tahun) yaitu sebanyak 30 orang $(24,1 \%)$ selanjutnya berturut-turut responden dengan tingkat pendidikan Tamat SD (6 tahun) yaitu sebanyak 18 orang (20,5\%), tingkat pendidikan Tamat SMP (9 tahun) yaitu sebanyak 16 orang (20,5\%), tingkat pendidikan Tamat D1-D3/S1 (13-17 tahun) yaitu sebanyak 13 orang $(14,8 \%)$, Tidak Sekolah (0 tahun) yaitu sebanyak 7 orang (8\%), Tidak Tamat SD (1-6 tahun) yaitu sebanyak 4 orang $(4,5 \%)$, dan pada penelitian ini tidak ditemukan responden yang memiliki tingkat pendidikan Pascasarjana (> 17 tahun).

Terdapat 45 orang $(51,1 \%)$ yang mempunyai riwayat hipertensi dan 43 orang $(48,9 \%)$ yang tidak mempunyai riwayat hipertensi. Sedangkan untuk responden yang memiliki riwayat DM terdapat 64 orang $(72,7 \%)$ dan 22 orang $(27,3 \%)$ yang tidak mempunyai riwayat DM.

Persentase responden yang merokok sebesar yaitu $37,5 \% \quad(30$ orang) dan hanya 2 orang $(2,3 \%)$ yang meng-konsumsi alkohol.

Pada penelitian ini responden yang mengkonsumsi buah dalam kategori cukup, masih rendah yaitu 20 orang $(22,7 \%)$ begitu pula responden yang mengkonsumsi sayur yaitu 16 orang $(18,2 \%)$. Selain itu, mayoritas responden melakukan aktivitas fisik ringan yaitu sebanyak 40 orang $(45,5 \%)$.

\section{Hubungan Karakteristik Responden, Riwayat Hipertensi, Riwayat DM, Perilaku Responden dengan Kejadian DM Tipe 2.}

Hasil uji statstik menggunakan uji chi square $\left(\mathrm{x}^{2}\right)$ dengan $\alpha=0,05$ mengenai hubungan karakteristik responden, riwayat hipertentis, riwayat DM, merokok, konsumsi buah dan sayur, dan aktivitas fisik dengan kejadian $\mathrm{dm}$ tipe 2 dijabarkan pada tabel

Tabel 2 Hubungan Karakteristik Responden, Riwayat Hipertensi, Riwayat DM, Merokok, Konsumsi Alkohol, Konsumsi Buah dan Sayur, dan Aktivitas Fisik dengan Kejadian DM Tipe

\begin{tabular}{|c|c|c|c|c|c|c|c|c|}
\hline \multirow{2}{*}{\multicolumn{2}{|c|}{ Variabel }} & \multicolumn{4}{|c|}{ DM Tipe 2} & \multirow{2}{*}{$\begin{array}{c}p- \\
\text { value }\end{array}$} & \multirow{2}{*}{ PR } & \multirow{2}{*}{$\begin{array}{c}\text { Confidence } \\
\text { Interval } \\
95 \%\end{array}$} \\
\hline & & $\mathrm{Ya}$ & $\%$ & Tidak & $\%$ & & & \\
\hline \multirow{4}{*}{$\begin{array}{l}\text { Kelompok } \\
\text { Umur } \\
\text { (tahun) }\end{array}$} & $25-34$ & 0 & 0 & 1 & 4,2 & 0,239 & - & - \\
\hline & $35-44$ & 2 & 3,8 & 3 & 12,5 & 0,099 & 0,196 & $0,030-1,284$ \\
\hline & $45-54$ & 11 & 17,7 & 5 & 20,8 & 0,522 & 0,647 & $0,194-2,156$ \\
\hline & $55-64$ & 51 & 79,7 & 15 & 62,5 & \multicolumn{3}{|c|}{ Pembanding } \\
\hline \multicolumn{2}{|c|}{ Total } & 64 & 100 & 24 & 100 & & & \\
\hline Jenis & Laki-laki & 24 & 37,5 & 12 & 50,0 & \multirow{2}{*}{0,413} & \multirow{3}{*}{0,600} & \multirow{2}{*}{$0,233-1,546$} \\
\hline Kelamin & Perempuan & 60 & 62,5 & 12 & 50,0 & & & \\
\hline \multicolumn{2}{|c|}{ Total } & 64 & 100 & 24 & 100 & & & \\
\hline
\end{tabular}




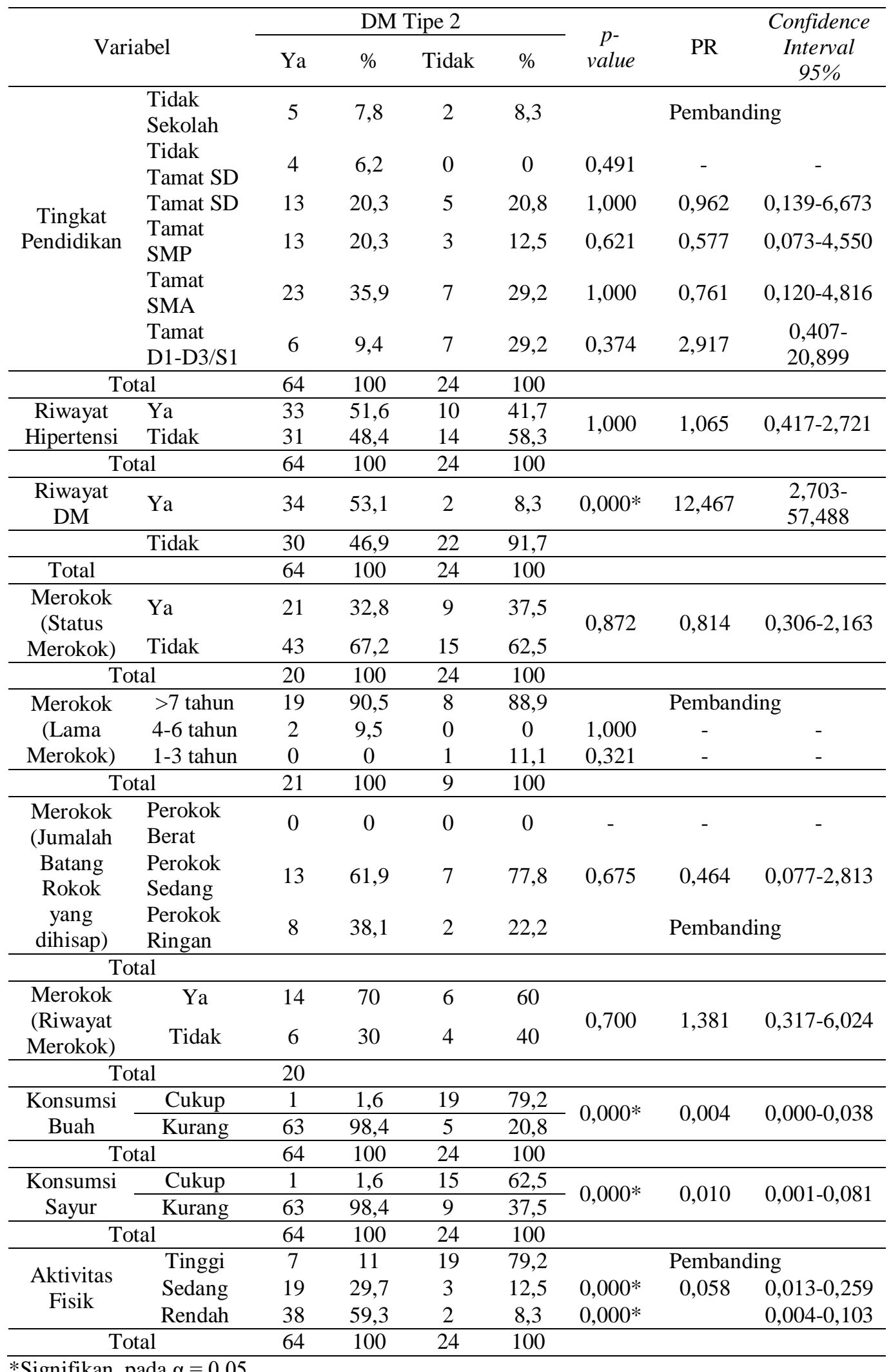

*Signifikan pada $\alpha=0,05$ 

Tidak dilakukan uji statistik untuk menentukan hubungan antara variabel konsumsi alkohol dengan kejadian DM tipe 2. Hal ini dikarenakan seluruh responden yang berjenis kelamin perempuan tidak ada yang mengkonsumsi alkohol dan untuk responden yang berjenis kelamin laki-laki yang mengkonsumsi alkohol tidak mencapai $50 \%$.

Berdasarkan hasil pada penelitian melalui uji chi square $\left(\mathrm{x}^{2}\right)$ dengan $\alpha$ $=0,05$ pada tabel 2 diketahui terdapat hubungan yang signifikan pada riwayat DM $(p=0,000)$, konsumsi buah dan sayur $(\mathrm{p}=0,000)$, dan aktivitas fisik ( $\mathrm{p}=$ $0,000)$ dengan DM tipe 2 sedangkan tidak terdapat hubungan yang signifikan pada umur $(\mathrm{p}=0,239\{25-34$ tahun vs $55-64$ tahun $\}, \mathrm{p}=0,099$ \{35-44 tahun vs 55-64 tahun $\}$, dan $\mathrm{p}=0,522 \quad\{45-54$ tahun vs 55-64 tahun $\})$, jenis kelamin (p $=0,413)$, riwayat pendidikan $(\mathrm{p}=0,491$ $\{$ Tidak Sekolah vs Tidak Tamat SD $\}, p=$ 1,000 \{Tidak Sekolah vs Tamat SD\}, p = 0,621 \{Tidak Sekolah vs Tamat SMP\}, p $=1,000$ TTidak Sekolah vs Tamat SMA $\}$, dan $\mathrm{p}=0,374$ \{Tidak Sekolah vs Tamat $\mathrm{D} 1-\mathrm{D} 3 / \mathrm{S} 1\})$, riwayat hipertensi $(\mathrm{p}=$ 1,000 ), merokok (status merokok nilai $\mathrm{p}$ $=0,872$, lama merokok $\mathrm{p}=1,000\{4-6$ tahun vs $>7$ tahun $\}$ dan $p=0,321\{1-3$ tahun vs $>7$ tahun , jumlah batang rokok yang dihisap nilai $\mathrm{p}=0,675$ \{perokok sedang vs perokok ringan\}, riwayat merokok nilai $p=0,700$ ), dan konsumsi alkohol dengan DM tipe 2.

\section{PEMBAHASAN}

\section{Karakteristik Responden}

Menurut data laporan tahunan mengenai kejadian DM tipe 2 di Kota Malang, selama dua tahun berturut-turut yaitu tahun 2015 dan tahun 2016 kelompok umur yang menderita DM tipe 2 terbanyak terdapat pada kelompok umur 60-69 tahun (Dinkes Kota Malang, 2016). Hal tersebut sesuai dengan data RISKESDAS (2007) bahwa terdapat kecenderungan prevalensi DM tipe 2 akan meningkat dengan bertambahnya umur (Depkes, 2008b). Pada penelitian ini tidak terdapat hubungan antara umur dengan kejadian DM tipe 2. Namun, bertambahnya prevalensi DM tipe 2 yang disertai dengan bertambahnya umur bukan berarti umur menjadi faktor risiko DM tipe 2, sesuai dengan hasil nilai PR pada pada penelitian ini yang mana umur merupakan faktor protektif terjadinya DM tipe 2. Menurut Leroith (2012) bahwa kejadian DM tipe 2 pada golongan umur tua terjadi lebih dikarenakan faktor lingkungan bukan hanya dari faktor fisiologis. Hal ini didukung oleh penelitian yang dilakukan oleh Emma \& Idris (2014) bahwa serangan dari DM tipe 2 pada orang dewasa lebih dikarenakan individu tersebut obesitas, mempunyai riwayat keturunan DM tipe 2, pola hidup yang tidak sehat, serta ras kulit hitam.

Berdasarkan hasil uji analisis diketahui bahwa hubungan antara jenis kelamin dengan kejadian DM tipe 2 tidak signifikan secara statistik. Penelitian yang dilakukan oleh Leslie dkk (2013) menjelaskan bahwa sebenarnya kejadian DM tipe 2 lebih rentan terjadi pada orang yang berjenis kelamin laki-laki dibandingkan dengan perempuan akan tetapi kenyataannya dilapangan orang yang berjenis kelamin perempuan lebih banyak terkena DM tipe 2 dibandingkan dengan laki-laki. Hal ini dikarenakan, perempuan di masyarakat mempunyai angka harapan hidup lebih tinggi dibandingkan dengan laki-laki sehingga semakin banyak perempuan lanjut usia menyebabkan jumlah perempuan yang mengidap DM tipe 2 semakin tinggi (Leslie dkk, 2013). Selain itu menurut Willer dkk (2016) diketahui bahwa peningkatan linggar pinggang pada perempuan sejalan dengan bertambahnya umur dibandingkan dengan laki-laki. Hal tersebut telah dikonfirmasi berdasarkan penelitian kohort dari berbagai negara. Pada analisis gabungan dari dua studi kohort berbasis populasi prospektif, perempuan di Jerman yang mendapatkan peningkatan $1 \mathrm{~cm}$ lingkar pinggang memiliki peningkatan risiko terkena DM tipe 2 sebesar $31 \%$ per tahun dan peningkatan risiko sebesar $28 \%$ per tahun jika perempuan tersebut memiliki 
peningkatan $1 \mathrm{~kg}$ berat badan (Willer dkk, 2016). Sedangkan bagi laki-laki peningkatan $1 \mathrm{~cm}$ lingkar pinggang memiliki peningkatan risiko terkena DM tipe 2 sebesar sebesar $29 \%$ per tahun dan peningkatan risiko sebesar 34\% per tahun jika laki-laki tersebut memiliki peningkatan $1 \mathrm{~kg}$ berat badan (Willer dkk, 2016).

Berdasarkan hasil penelitian diketahui bahwa hubungan antara tingkat pendidikan dengan kejadian DM tipe 2 tidak signifikan secara statistik serta semua tingkat pendidikan merupakan faktor protektif terjadinya DM tipe 2 kecuali tingkat pendidikan Tamat D1D3/S1 meningkatkan/memperbesar risiko terjadinya DM tipe 2. Meskipun hasil perbandingan antara tingkat pendidikan tinggi (> Tamat D1-D3/S1) dengan tingkat pendidikan rendah (< Tamat SMA) yang sama-sama menderita DM tipe 2 yaitu sebesar $6(9,4 \%): 58$ $(90,6 \%)$. Penelitian yang di lakukan oleh Olsson (2011) menjelaskan bahwa tingkat pendidikan tinggi (> Tamat D1D3/S1) berhubungan dengan peningkatan risiko autoimun DM tipe 2 . Responden yang memiliki tingkat pendidikan tinggi (> Tamat D1-D3/S1) mempunyai level C-peptida yang rendah, memiliki level anti-GAD yang lebih tinggi, dan lebih sering melakukan pengobatan insulin (Olson, 2011). Hal ini juga didukung oleh data dari RISKESDAS (2013) bahwa prevalensi DM tipe 2 cenderung lebih tinggi terjadi pada masyarakat yang memiliki tingkat pendidikan tinggi serta dengan kuintil indeks kepemilikan tinggi yaitu sebesar 2.5\% (Kementerian Kesehatan RI, 2014).

Berdasarkan hasil uji analisis diketahui bahwa tidak terdapat hubungan yang signifikan antara riwayat hipertensi dengan kejadian DM tipe 2. Akan tetapi, besar nilai $\mathrm{PR}=1,065$, menunjukkan bahwa riwayat hipertensi meningkatkan/ memperbesar risiko terjadinya DM tipe 2 sebesar 1,1 kali. Menurut penelitian yang dilakukan oleh Nayak dkk (2017) di Trinidad India diketahui bahwa ketika terjadi peningkatan keparahan hipertensi, prevalensi DM tipe 2 juga meningkat.
Data berikut ini mengkonfirmasi bahwa hipertensi dan DM tipe 2 saling berhubungan, peningkatan bertahap pada penderita DM tipe 2 dari tekanan darah normal (37,2\%), menjadi pre-hipertensi $(47,7 \%)$, dari pre-hipertensi menjadi hipertenis tahap 1 sebesar $61,4 \%$ dan meningkat sedikit menjadi $63,5 \%$ pada hipertensi tahap 2, hal tersebut merupakan bukti adanya komorbiditas (Nayak dkk, 2017). Hal ini didukung oleh penelitian dari Rahayu dkk (2012:27) bahwa hipertensi yang terjadi dalam waktu yang lama (kronis) dapat menyebabkan stroke, gangguan fungsi ginjal, penyakit jantung koroner, gangguan penglihatan, resistensi insulin dan merupakan salah satu faktor risiko DM tipe 2. Namun, mekanisme yang menghubungkan antara hipertensi dengan resistensi insulin masih belum jelas, meskipun sudah diketahui dengan jelas bahwa resistensi insulin adalah penyebab utama peningkatan kadar glukosa darah (Rahayu dkk, 2012).

Pada penelitian ini terdapat hubungan yang sangat signifikan antara riwayat DM dengan Kejadian DM tipe 2. Besar risiko responden yang mempunyai riwayat DM dibandingkan dengan yang tidak mempunyai riwayat DM untuk mengalami DM tipe 2 adalah sebesar 12,5 kali. Berdasarkan penelitian yang dilakukan oleh Katulanda (2014) diketahui bahwa pada pasien yang menderita DM tipe 2 terdapat peningkatan tekanan darah sistolik dan diastolik, gula darah puasa, koleserol total serta trigliserida. Gula Darah Puasa (GDP) terganggu (100-125 mg/dl) dan Toleransi Glukosa Tergangu (TGT) (140-199 $\mathrm{mg} / \mathrm{dl})$ merupakan suatu gejala pada prediabetes (Depkes, 2013). Hal ini didukung oleh Kementerian Kesehatan RI (2014) riwayat Toleransi Glukosa Terganggu (TGT) dan Gula Darah Puasa terganggu (GDP terganggu) merupakan salah satu faktor risiko DM yang dapat dimodifikasi.

Berdasarkan hasil uji analisis diketahui bahwa tidak terdapat hubungan yang signifikan antara merokok (lama merokok, jumlah batang rokok yang 
dihisap, dan riwayat merokok) dengan kejadian DM tipe 2. Sejalan dengan penelitian yang dilakukan oleh Kufe dkk (2015) bahwa tidak terdapat hubungan yang bermakna antara perokok aktif dan mantan perokok dengan kejadian DM tipe 2. Akan tetapi, besar nilai PR (riwayat merokok) $=1,381$, sehingga riwayat merokok meningkatkan /memperbesar risiko terjadinya DM tipe 2 sebesar 1,4 kali. Hal ini sesuai dengan penelitian yang dilakukan oleh Yufang dkk (2012) bahwa terdapat beberapa mekanisme yang berkontribusi pada hubungan antara merokok dengan DM tipe 2. Perokok aktif cenderung lebih kurus dibandingkan dengan orang yang tidak perokok atau mantan perokok, namun perokok akan cenderung mengalami peningkatan berat badan ketika mereka berhenti merokok dan mantan perokok berat dan sedang akan lebih gemuk dibandingan mantan perokok yang ringan (Yufang dkk, 2012). Meskipun dengan indeks masa tubuh yang normal, perokok cenderung berisiko mempunyai obesitas sentral dibandingkan dengan bukan perokok, hal ini dikarenakan merokok mempunyai efek antiestrogen dan dapat merusak keseimbangan hormon serta menyebabkan obesitas sentral dimana obesitas secara keseluruhan dan obesitas sentral mempunyai hubungan yang kuat dalam peningkatan kejadian DM tipe 2 (Yufang dkk, 2012). Merokok diidentifikasi sebagai faktor risiko dari resistensi insulin, yang mana merupakan prekursor dari kejadian DM tipe 2 selain itu, merokok dapat memperburuk metabolisme dari glukosa dimana hal tersebut dapat memicu terjadinya DM tipe 2 (Seifu, 2015).

Pada penelitian ini seluruh responden yang berjenis kelamin perempuan tidak ada yang mengkonsumsi alkohol dan untuk responden yang berjenis kelamin laki-laki yang mengkonsumsi alkohol tidak mencapai 50\% sehingga tidak dapat dilakukan uji analisis untuk mengetahui hubungan antara konsumsi alkohol dengan kejadian DM tipe 2 . Yufang dkk (2012) menyatakan bahwa konsumsi alkohol dengan intensitas sedang dapat meningkatkan sensitivitas insulin, meningkatkan level kekentalan dari kolesterol dan adinopektin, serta dapat menurunkan penyebab radang pada tenggorokan. Akan tetapi, konsumsi alkohol dengan intensitas berat dapat memicu terjadinya obesitas sentral serta dapat merusak fungsi liver sehingga memicu pankreatitis dimana itu semua merupakan beberapa hal yang berperan dalam timbulnya DM tipe 2 (Yufang dkk, 2012).

Pada penelitian ini terdapat hubungan yang signifikan antara konsumsi buah dan sayur dengan kejadian DM tipe 2. Sejalan dengan penelitian yang dilakukan oleh Amirudin dkk (2014) di Wajo Sulawesi Selatan bahwa terdapat hubungan yang bermakna antara konsumsi buah dan sayur dengan kejadian DM tipe 2. Proporsi insiden kejadian DM tipe 2 yaitu 2,91 kali untuk responden yang kurang mengkonsumsi buah dan sayur dibandingkan dengan responden yang cukup mengkonsumsi buah dan sayurnya. Rendahnya konsumsi buah dan sayur pada seseorang mempunyai hubungan yang bermakna pada peningkatan berat badan serta terjadinya DM tipe 2 (Bhattacherjee dkk, 2015). Pada program pencegahan diabetes (Diabetes Prevention Program/DPP) menganjurkan untuk mengurangi makanan yang menyebabkan peningkatan berat badan dan lebih meningkatkan intensitas makanan yang banyak mengandung serat $(\mathrm{Wu} \mathrm{dkk}$, 2014). Selain untuk menjaga berat badan, makanan yang mengandung serat terutama yang mengandung nilai indeks glikemik rendah seperti sereal, kacangkacangan, anggur, kentang dapat menghindari kenaikan dan penurunan kadar gula yang ekstrem pada penderita DM tipe 2 (Asif, 2011:33).

Berdasarkan hasil penelitian diketahui bahwa terdapat hubungan yang bermakna antara aktivitas fisik dengan kejadian DM tipe 2. Hal ini sejalan dengan penilitian yang dilakukan oleh Amirudin dkk (2014) bahwa aktivitas fisik seseorang mempunyai hubungan 
yang signifikan terhadap insiden dari DM tipe 2. Aktivitas fisik seseorang berkontribusi 30-50\% mengurangi perkembangan dari DM tipe 2. Aktivitas fisik dapat meningkatkan toleransi glukosa dalam darah dan mengurangi faktor risiko kejadian DM tipe 2 (Wu dkk, 2014:1194). Pada penelitian ini responden mayoritas responden yang menderita DM tipe 2 adalah golongan umur 55-64 tahun sebanyak 51 orang, untuk itu aktivitas fisik yang sesuai dengan golongan umur tersebut sebaiknya memenuhi kriteria FITT (frequency, intensity, time, type) (Barisic dkk, 2011). Frekuensi merupakan seberapa sering aktivitas fisik dilakukan (berapa hari dalam seminggu). Intensitas adalah seberapa keras aktivitas fisik dilakukan (aktivitas fisik tinggi, sedang, dan rendah). Waktu berkaitan dengan seberapa lama aktivitas fisik dilakukan (jam atau menit). Jenis merupakan jenisjenis aktivtias fisik yang dilakukan (Barisic dkk, 2011). WHO (2010) merekomendasikan aktivitas fisik yang telah memenuhi kriteria FITT dan sesuai dengan golongan umur 55-64 tahun yaitu dengan jenis olahraga aerobik paling sedikit 10 menit, melakukan aktivitas fisik intensitas sedang $150 \mathrm{menit} / \mathrm{minggu}$ (bersih-bersih rumah, menyapu, setrika, mencuci, berkebun, menenun) atau melakukan aktivitas fisik intensitas tinggi 75 menit/minggu (berjalan, berenang bersepada). Selain olah raga aerobik perlu melakukan aktivitas fisik yang menunjang untuk penguatan otot yaitu dengan aktivitas fisik melawan gravitasi dapat berupa gerakan berdiri dari kursi ditahan beberapa detik dan dilakukan berulang ulang ( 1 set 10 kali) dengan intensitas 2 kali seminggu (WHO, 2010). Untuk golongan umur 55-64 tahun yang memiliki kesulitan mobilitas disarankan untuk melakukan aktivitas fisik yang meningkatkan keseimbangan dan mencegah jatuh dengan intensitas 3 kali seminggu (WHO, 2010).

\section{KESIMPULAN}

Berdasarkan hasil penelitian, dapat diperoleh kesimpulan sebagai berikut: (1) Kejadian DM tipe 2 sebanyak 64 orang $(72,7 \%)$ dengan distribusi karakteristik rata-rata dengan kelompok umur 55-64 tahun (66 orang), mayoritas berjenis kelamin perempuan sebanyak 52 orang $(59,1 \%)$, tingkat pendidikan Tamat SMA (30 orang), proporsi res-ponden yang mempunyai ri-wayat hipertensi sebanyak 41 orang dan riwayat DM sebanyak 66 orang. (2) Dilihat dari faktor risiko berupa perilaku responden merokok yaitu terdapat 29 orang, mayoritas telah merokok selama > 7 tahun, jumlah batang rokok yang dihisap setiap hari 10-20 batang, dan hanya sedikit responden yang saat ini masih menjadi perokok aktif. Konsumsi alkohol responden yaitu sebanyak 2,3\% dan berjenis kelamin laki-laki serta tidak terdapat responden yang meng-konsumsi alkohol dalam kurun waktu satu bulan terakhir. Kon-sumsi buah dan sayur responden yaitu mayoritas kurang $(<5$ porsi/hari). Aktivitas fisik res-ponden yaitu mayoritas me-lakukan aktivitas fisik ringan. Tidak terdapat hubungan yang bermakna antara umur, jenis kelamin, tingkat pendidikan, riwayat hipertensi, merokok, dan konsumsi alkohol dengan kejadian DM tipe 2 . Namun, terdapat hubungan yang bermakna antara riwayat DM, konsumsi buah dan sayur, dan aktivitas fisik dengan kejadian DM tipe 2.

\section{SARAN}

Berdasarkan hasil penelitian, pembahasan, dan kesimpulan, maka saran yang dapat diuraikan sebagai berikut:

1. Puskesmas Kendalkerep sebaiknya melakukan Meningkatkan pelayanan preventif dan promotif dengan penyuluhan mengenai DM tipe 2 kepada pasien dan keluarga pasien yang berada di ruang tunggu puskesmas secara langsung melalui poster atau media (seperti video/film) untuk pelayanan kuratif berupa pemantauan pasien DM tipe 2 setiap bulan agar tidak terjadi komplikasi. 
2. Bagi pasien DM tipe 2 di Puskesmas Kendalkerep sebaiknya melakukan konsultasi diet DM tipe 2 dengan dokter, mengkonsumsi makanan yang tinggi serat terutama yang mengandung indeks glikemik rendah (kacang-kacangan, sereal, anggur, dan kentang) serta mengurangi makanan yang menyebabkan peningkatan berat badan. Mengikuti senam prolanis yang diadakan oleh puskesmas setiap hari jumat. Selain itu, pasien DM tipe 2 harus tetap melakukan aktivitas fisik di rumah dengan melakukan olahraga aerobik, melakukan aktivitas fisik yang menunjang Amirudin, R dkk. 2014. Diabetic Mellitus Type 2 in Wajo South Sulawesi Indonesia. Internatioanl Journal of Current Research and Academic Review, 2 (12) : 1- 8.

Asif, M. 2011. The Role of Fruits, Vegetables, and Spices in Diabetes. International Journal of Nutrition. 1(1): 27-35.

Barisic, Andriana dkk. 2011. Importance of Frequency, Intensity, Time and Type (FITT) in Physical Activity Assessment for Epidemiological Research. Journal Public Health. 102 (4): 174-175.

Bhattacherjee, Sharmistha dkk. 2015. A Cross-sectional Assessment of Risk Factors of NonCommunicable Disease in a SubHimalayan Region of West Bengal, India Using WHO STEPS Approach. Journal of The Association of Physicians of India. 63:34-40.

Departemen Kesehatan Republik Indonesia. 2008a. Petunjuk Teknis Pengukuran Faktor Risiko Diabetes Mellitus. Jakarta. Direktorat Pengendalian Penyakit dan Penyehatan Lingkungan Departemen Kesehatan Republik Indonesia.

Departemen Kesehatan Republik Indonesia. 2008b. Riset untuk penguatan otot, dan golongan umur 55-64 tahun yang memiliki kesulitan mobilitas disarankan untuk melakukan aktivitas fisik yang me-ningkatkan keseimbangan dan mencegah jatuh.

3. Bagi peneliti selanjutnya Melanjutkan penelitian mengenai analisis faktor risiko DM tipe 2 dengan menggunakan pendekatan WHO STEPwise Step 1 tambahan (expanded), dan pilihan (optional) serta Step 2 dan 3 baik inti (core), tambahan (expanded), dan pilihan (optional).

\section{DAFTAR RUJUKAN}

Kesehatan Dasar (RISKESDAS 2007). Jakarta: Badan Penelitian dan Pengembangan Departemen Kesehatan Republik Indonesia.

Departemen Kesehatan Republik Indonesia. 2013. Riset Kesehatan Dasar 2013. Jakarta: Badan Penelitian dan Pengembangan Kesehatan Kementrian Kesehatan RI Tahun 2013.

Dinas Kesehatan Kota Malang. 2016. Laporan Penyakit Tidak Menular di Kota Malang tahun 2013 2016. Malang: Bidang Pengendalian Penyakit dan Penyehatan Lingkungan (P2PL) Dinas Kesehatan Kota Malang.

Emma, Wilmot \& Idris, Iskandar. 2014. Early Onset Type 2 Diabetes: Risk Factor, Clinical Impact, and Management. Journal Therapeutic Advance in Chronic Disease. 5 (6): 234-244.

International Diabetes Federation. 2015. IDF Diabetes Atlas Seventh Edition 2015. Brussels: International Diabetes Federation.

Katulanda, P. 2014. The Influence of Family History of Diabetes on Disease Prevalance And Associated Metabolic Risk Factors Among Sri Lankan Adults. Journal Diabetic Medicine. :1-10 
Kementerian Kesehatan Republik Indonesia. 2014. Infodatin Diabetes. Jakarta Selatan: Pusat Data dan Informasi Kementerian Kesehatan Republik Indonesia.

Krisnatuti, D., Rasjmida, D., \& Yenrina, R. 2014. Diet Sehat untuk Penderita Diabetes Mellitus. Jakarta Timur: Penebar Swadaya.

Kufe, dkk. 2015. Risk Factor of Impaired Fasting Glucose and Type 2 Diabetes in Yaounde, VCameroon: A Cross Sectional Study. Journal BMC Public Health. 1:10.Lembaga Penyelidikan Ekonomi dan Masyarakat. 2010. Indonesia Economic Outlook 2010. Jakarta: Grasindo.

Leroith, Derek. 2012. Prevention of Type 2 Diabetes. New York: Springer.

Leslie, David, dkk. 2013. Diabetes: Clinician's Desk Reference. New York: CRC Press.

Mihardja, L., Soetrisno, U., \& Soegondo, S. 2013. Prevalence and clinical profile of diabetes. Journal of Diabetes of Investigation, 5: 507-512.

Nayak, dkk. 2014. The Association of Age, Gender, Ethnicity, Family History, Obesity, and Hypertension With Type 2 Diabetes Meliitud in Trinidad. Journal Diabetes Metabolic Syndrom Elsevier. 8 (2): 91-95.

Olson. 2011. High Levels of Education Are Associated With an Increased Risk of Latent Autoimmune Diabetes in Adults Results from the Nord Trondelag Health Study. Journal Diabetes Care. 34(1): 102-107.

Puskesmas Kendalkerep. 2015. Laporan Bulanan Tahun 2013 dan 2014. Malang:Puskesmas Kendalkerep

Rahayu, Puji, dkk. 2012. Hubungan Antara Faktor Karakteristik, Hipertensi, dan Obesitas dengna Kejadian Diabellitus Mellitus di Rumah Sakit Umum Daerah Dr. H. Soewondo Kendal. Jurnal
Universitas Muhammadiyah Semarang. 26-32

Seifu, Wuabreg. 2015. Prevalence and Risk Factor For Diabetes Mellitus and Impaired Fasting Glucose among Adults Age 15-64 Years in Gilgel Gibe Field Research Center, Southwest Ethiopia, 2013: Through a WHO Step Wise Aproach. Journal MOJ Public Health. 2 (4): 1-8.

Widjajanta, Bambang. 2007. Mengasuh Kemampuan Ekonomi. Jakarta: CV. Citra Praya.

Willer, Alexandra Kautzky, dkk. 2016. Sex and Gender Differences in Risk, Pathophysiology and Complication of Type 2 Diabetes Mellitus. Journal Endocrin Review. 37 (3): 278-316.

World Health Organization. 2003. STEPS: A framework for Surveillance. Geneva: Noncommunicable Diseases and Mental Health World Health Organization.

World Health Organization. 2010. Global Recommendations on Physical Activity for Health. Geneva. World Health Organization.

World Health Organization. 2011. WHO STEPwise Approach to Chronic Disease Risk Factor Surveillance (STEPS). Promotion Of Fruit and Vegetable for Health African Regional Workshop for Anglophone Countries . Tanzania: World Health Organization.

World Health Organization. 2016a. Global Report on Diabetes. Geneva: World Health Organization.

World Health Organization. 2016b. Country and regional data on diabetes. (Online), (http://www.who.int/diabetes/fact s/world_figures/en/index5.html), diakses pada tanggal 03 Oktober 2016.

Wu, Yanling dkk. 2014. Risk Factor Contributing to Type 2 Diabetes and Recent Advances in the 
Treatment and Prevention.

International Journal of Medical Sciences. 11(11): 1185-1200.
Yufang, Bi, dkk. 2012. Advanced Research on Risk Factors of Type 2 Diabetes. Wiley Online Library, 28 (2): 32-39. 